\title{
What is Straussianism (According to Strauss)?
}

\author{
Peter Augustine Lawler
}

Published online: 24 November 2010

(C) Springer Science+Business Media, LLC 2010

Straussianism is under attack from many quarters today. Both liberals and conservatives blame the movement originated by the political philosopher Leo Strauss for a covert elitism, American imperialism, a neo-conservatism that's akin to neo-Fascism, a Machiavellian contempt for ordinary human decency, and a spiritual or anti-spiritual struggle against our Christian heritage. Our intellectual world, as Peter Minowitz has chronicled, suffers from "Straussophobia."

That there are Straussians today nobody can deny, a group of scholars and intellectuals with a fairly coherent approach to both political thought and dealing with the crisis of our time. That Strauss intentionally aimed at producing something like Straussians - a school of thought with a genuine esprit de corps - is also not seriously in doubt. But what Straussianism is exactly remains a bone of contention. For one reason, Strauss is famous for almost shouting that great thinkers have characteristically had secret or esoteric teachings. What they really think is true is found between the lines and often contradicts what they seem to say in the actual lines.

My purpose here is to examine Strauss's arguably most programmatic book-What Is Political Philosophy? —with the intention of showing that what Strauss meant to do is more comprehensible and more benign than his critics usually say, although "Straussianism," like any "ism," aims to produce a kind of self-confidence that remains quite questionable. It is, in fact, even of questionable relevance for the challenges we now face, which is not to say that it did not make an important contribution to our victories

P. A. Lawler (四)

Berry College,

Mount Berry, GA 30149-0118, USA

e-mail: plawler@berry.edu against the Historical ideologies of Communism and the various forms of Fascism.

Strauss himself knew that philosophy or philosophers always produce sectarianism. Philosophic sects or schools and philosophic doctrines are necessary for philosophy to change the world. The "zetetic" or incessantly questioning spirit that Strauss attributes to pure philosophy has to be compromised for all kinds of practical reasons. That's why, for example, Strauss repeatedly highlighted the fact that Socrates and the sophist Thrasymachus necessarily become friends during the quest for a just city in the Republic. Pro-philosopher sophists or intellectuals with political ambition and rhetorical savvy are required to persuade people - with methods that aren't fully rational- to do what the philosopher thinks best. That doesn't mean that what the philosopher wants isn't good or even that the people are in the intractable thrall of prejudice. It's just that people, for good reason, can't be persuaded by reason alone. They're rightly reluctant to surrender their freedom to men who think they know better than them, and they know that men who do nothing but question think they've talked themselves out of their duty to be of service to their fellow men.

\section{Historicism and Platonism}

In his essay on the admirable intellectual Kurt Riezler, Strauss writes, "If we are permitted to say that historicism is the view according to which at least all concrete or profound thought essentially belongs to a concrete dynamic context, and that Platonism is the view that pure thought, being 'anonymous,' transcends every dynamic context..." Historicism and Platonism, we might be permitted to say, are two extremes. 
They are, for Strauss, on one level two serious claims about the relationship between human thought and Being. Do human beings have an access to a truth that is eternal or does what we think or know change over time? Because any "concrete dynamic context" is essentially an interaction between human creativity and impersonal natural forces, the view of historicism is that what we can know depends on who we are at any particular time. The who is prior to the what, and the who is always in the process of Historical self-transformation. There is no natural or eternal stability that's at the foundation of what we know or who we are.

To attempt to think about what is according to nature without thinking about who we are is to think abstractly or self-forgetfully, and the who is the being who acts Historically or not according to nature. Certainly our destinies as free beings aren't given to us by nature-and certainly we don't create them at some particular moment out of nothing. In our freedom we transform nature or impose ourselves on what we're given, but our freedom is always limited or socially contextual. So both who we are and what we're supposed to do depends on our concrete location in a particular historical time and place, in a particular "dynamic" or changeable context.

The view of Platonism is that the most profound or true answers about who we are and what we're supposed to do have been given to us by nature-a nature that's knowable as eternal and impersonal or incapable of being changed by any form of personal creativity. For the Platonist, the human or Socratic drama is the particular human being coming to know the eternal or impersonal truth. Being a Platonic philosopher is learning how to die or to surrender all pretensions about one's own, ephemeral being in the light of eternity. The truth doesn't depend on some human perspective; knowing it, in fact, requires a kind of negation of the human or personal perspective. The ascent toward what is true always requires shedding concern for one's own individuality or personality.

As two forms of extremism, historicism and Platonism are also two "isms" or ideologies-two philosophic doctrines presented as human solutions. They are, as Strauss says, the foundation of the modern and classical solutions; neither of which he accepts as the solution. As Strauss says in the last paragraph of his polemic against the exemplary historicist Alexandre Kojève - the one he left out of What Is Political Philosophy? - neither identifying Being wholly with history or time or dynamic context or identifying Being wholly with eternal necessity seems self-evident to him.

For Strauss, actually, the deepest distinction is not between Platonic "natural right" and Hegelian or Heideggerian "History." It is between identifying Being with Eternity or Being with Creativity. If Being is caused by creativity, then human beings are, finally, free from natural necessity. That freedom might be the gift of a loving, providential God. Or it might be the product of human beings gaining their freedom from nature through their personal or historical creativity. Either way, Being is personal. Either way, man is made, even if he makes himself (as the John Locke illuminated by Strauss explains) in the image of a free, creative, and loving God. From one view, the issue that separates the greatest human thinkers is whether human eros or love is, most deeply, personal or finds its real culmination or satisfaction in knowledge of impersonal or eternal natural necessity. Do we most deeply long for a "who" or a "what"? Is God himself a who or a what? For Strauss, famously, the right question is "What is God?"

For Strauss, the Platonic truth is that Being is nothing personal, and that means that those who pursue the eternal truth have no deep attachment to the pursuit of personal freedom - a pursuit which is based on illusions the classical philosopher doesn't share. For Strauss, the "supernatural" virtue of charity is based on the love of a personal God and so doesn't animate the classical philosopher. But for the modern philosophers, like the Christian theologian, being "supernatural" is no objection; Being itself is "supernatural" or imposed upon nature by free beings. And so philosophers, in pursuit of the truth, have, in a way, a duty to be charitable or to help us do what we can to free ourselves from our unfortunate natural misery. To use a very extreme example: Marx thought the revolution he helped incite would both free most human beings from their natural and their historical suffering or alienation and free the somewhat ignorant or alienated philosopher for the contemplation of wisdomfor knowing the whole of Being, History as a whole. Marx's charity was, in a way, real, but it certainly began at home.

\section{History and Its End}

The total liberation that would come at History's end would include, for Marx, total wisdom or seeing the logos of History as a completed whole. That prospect was apparently so exhilarating for him that he neglected to think that the end of History would necessarily be the end of humanity or a return to the impersonal logos of prehistorical nature that necessarily has no one to know it. One aspect of Strauss's objection to charity as a virtue is that it's really all about the effort to free people from the misery of being human, and that freedom would include both freedom from the nobility of living a morally demanding life and, more importantly, from the erotic longings - which are necessarily some mixture of intense pleasure and singular misery-that distinguish members of our species alone by nature. The highest or most genuine of these longings animates the 
philosopher or the being most animated by the human openness to the truth.

But the reason Strauss thought Kojève was the most rigorous of the historicist thinkers is that he understood that the end of History would produce the "reanimalization" of man, and in the name of his wisdom he was able to affirm that conclusion as both necessary and good. Human liberty or History was an error that needed to be corrected by all means necessary. And it can seem like charity to want alienated human beings enjoying once again the contentment readily available to all the other animals. Once History disappears, the Darwinians would be right that all the animals are hardwired to be happy. The Platonist view that at least philosophers are happy always depended on exceedingly rare and quite questionable evidence. So the ideology of Historicism is more charitable, backed up more by real evidence, and more attuned to the philosophic goal of wisdom than the ideology of Platonism.

The most compelling evidence against the ideology of historicism, of course, is that it was used by philosophers to justify Stalinist or Nazi tyranny by finding profound significance in the Historical activity of personal beingsbeings with names. The murderous crimes of Stalin were justified as the means necessary for taking the final step from the realm of necessity into the realm of freedom, as well as the final step from philosophy to wisdom. The philosopher Heidegger employed historicism to grossly overestimate the personal significance of Heidegger for Being itself. Heidegger really thought he was acting as a kind of philosopher-king or shepherd of Being by putting his personal stamp of profound approval on what happened to be happening in his country in 1933. He, like the Stalinist thinkers of about the same time, found profound significance in the victory in his country of the most immoderate, cruel, and humanly destructive political force.

\section{Taking Being Personally Today}

Those who take Being personally (in the Historical sense at least), Strauss shows us, are far too serious and dramatic or have an impoverished sense of humor and no sense of proportion. We have to add, though, that those who think they can rely on divine creativity to sustain their personal significance, as Machiavelli complained, think they can afford to be relatively laidback or not nearly so sweaty. Anyone who believes that Being is a gift of the Creator would sweat the coming of Nietzsche's "last man" or some kind of universal tyranny that would make philosophizing impossible a lot less than Strauss seemed to have done. He might even find Heidegger and Kojève at least a bit more amusing than Strauss seems to have done.
Decent men and women, of course, can't help but be repulsed by the historicist philosophers' identification of Being with what was obviously, to anyone with any common sense, the most bizarre and horribly cruel forms of collective insanity in human history. Sensible men and women think, of course, that nothing the Nazis or Communists could have done could have revealed to us who we are. The self-indulgent or self-induced madness of historicist ideology - and the disgusting personal irresponsibility of the intellectual who embraced it - now seem obvious to us all.

One thing that was wrong with identifying Being with History, of course, is that it turned particular persons with names into "History fodder." Their significance came not in who they are as unique and irreplaceable beings (as the Bible says), but in being sacrificed for either the coming end of History or their country's profound Historical destiny.

Theorists today, as far as I can tell, often oppose themselves to the sacrificing of unique and irreplaceable beings for God or country or history or anything else. They're willing to say we all have rights, but they don't look to religion or philosophy-given their repressive and murderous records - for any justification for their view of who they are. Decent people who care about people are repulsed by the record of modern philosophers (while, ironically, too often accepting rather uncritically the modern view of the cruelty, ignorance, and superstition that characterized the Christian centuries), and so they think they're stuck with claiming they don't need philosophy or theology to know who they are. The nonfoundationalism so fashionable today is a reasonable response to especially the later or more aggressively historicist forms of the modern philosophical project. In Heidegger's eyes, the truth has nothing to do with morality or our responsibility to persons, and for the Marxists the truth is that today's persons can be used as expendable means to achieve History's ends. The nonfoundationalist, accordingly, chooses against truth and for respect for personal dignity.

Strauss doesn't claim that Platonism or classical political philosophy can give any philosophic justification of the person's high opinion of his unique and irreplaceable significance. The possibility of such a justification depends on either a revealed theology about the creativity of the personal God or some form of modern or historicist or creative philosophy. Kojève made the powerful point that Strauss's choice of eternity over history is at the expense of denying real significance to particular human lives. Strauss didn't disagree. Strauss even agrees, in a way, with contemporary nonfoundationalists that the search for such a philosophic justification for personal significance or individuality has been a large part of the modern problem. 
Strauss's Platonism assures decent men and women, instead, that at least the exemplary philosophers - the classical philosophers - don't make any claims to profundity for anything human beings do-especially collectively or politically. From the point of view of the pure thinker contemplating eternity, everything people do is ephemeral and paltry —or, as even some Christian writers have said, nothing in light of eternity So the classical philosophers were never out to screw up people's lives to satisfy their personal needs. They thought that people were necessarily too screwed to respond reliably to any philosophic fix.

\section{The Dramatic Exaggeration of Platonism}

The most profound human drama of Platonism is the most perfect human being - a being with a name-becoming dead to himself (by, paradoxically, really knowing himself) and so becoming emotionally detached from the concerns of the people of his time and place through his encounter with the anonymous, eternal truth. He becomes, in fact, emotionally detached from all the moral longings most human beings share, because he doesn't see any evidence for the claims about human freedom and divine providence they can't help but presuppose. His freedom is, in part, freedom from the illusions about personal significance or freedom that animate most human beings. To the pure particularity or personal willfulness Strauss sees in revelation and to the attempted synthesis of universality and particularity - or reason and personal freedom-he sees in the Hegelian historicist Kojeve (and, for that matter, in Thomism), Strauss opposes the pure universality of pure thought.

For Strauss, the historicist exaggeration is that nothing human is natural or that to be free is to be detached from every necessity given to members of our species - to be free is to be detached from the laws of nature. Historicism, so understood, Strauss shows to be probably untrue but certainly pernicious. The necessitarian exaggeration of Platonism is both the theoretical and the political antidote to the pernicious exaggeration of radical historicism. Strauss's Platonism is obviously an aristocratic correction to the democratic or vulgar reduction of science or philosophy to technology - to a tool for merely personal freedom. Strauss' aristocratic Platonism has certainly inspired ambitious, intelligent, and idealistic young men and women to a proud or aristocratic contempt for the pretensions of practice. Against the historicists or the modern technologists who "theorize" practice, Straussianism restores the leisurely view that the contemplative life has nothing to do with practice. It means to cure them of the longing for justice in this world; mere justice-especially at the expense of excellence-is a democratic concern.
Platonism shows them the nobility of a way of life freed from the hopes, fears, and loves or all the moral impulses that point men in the direction of a personal God and other profound personal attachments.

The genuine aristocrat will not sacrifice himselfmeaning his soul-for causes that aren't his own, and part of his greatness of soul is to have his concerns distinguished from those that move most men and women. Freed from the charm of morality, he's also freed from the beliefs that would cause him to exaggerate either his freedom or the evils that plague us all. It goes without saying that Platonismbeing aristocratic - isn't really meant to obliterate all concern for personal significance, for the nobility of one's own life. The question of political philosophy remains personal-how should I live $m y$ life? - although my life, being as ephemeral as everyone else's, is nothing in the light of eternity. Being a philosopher becomes the answer of Platonism or Straussianism. But serving the cause of the philosopher or securing the conditions for philosophy's perpetuation becomes highly noble too.

How to serve that cause is, of course, highly contextual or depends on the dangers facing it in one's time and place or historical (with a little h) location, but the cause itself is eternal or what's always right by nature. The enemies of that cause are always animated by an angry and willful or spirited desire for dogmatic wisdom concerning their personal significance, and those who serve the cause know that it's part of the goodness of nature that philosophy - or the erotic quest to know what is always - can never be replaced by wisdom. The fundamental questions will never be displaced by authoritative answers. So it's knowledge of our invincible ignorance that's one source of authentic political prudence-our knowledge of the permanent limitations of political life.

\section{The True Platonic Insight}

Straussian Platonism is, of course, based on a true Platonic insight: The truth is that we don't know the "whole" or have a comprehensive, airtight account of what is always. And so, as Pascal says (and as Strauss quotes time and again), we know too much to be skeptics and too little to be dogmatists. Plato also knew that human beings couldn't live well without final answers. But it turns out, the Platonist asserts, that we do have one final answer-the way of life of the philosopher. The finality of that answer depends on its freedom from time or History or changes occasioned by what men do. Surely it turns out that even the praise of philosopher or the way of life of the philosopher, the essence of Platonism, is still based on an insight suspended in between skepticism and dogmatism, one at best provisionally true. It's because the permanent 
human questions have no absolutely compelling human answers that philosophy is the best way of life, but that means that at least one of the questions has been answered with finality and in a way that, in principle, subordinates every other question to that answer. And that personal answer seems to depend on the existence of an impersonal, eternal whole or cosmos that has no place for persons, a place which, as Strauss says, is the home of the human mind and so not of whole human beings.

Still, Strauss understood that Platonism is the finality most attractive to the first age that, as Nietzsche said, thinks we don't have "the truth." It's the truth appropriate to men who are aware that, at best, that they live suspended between skepticism and dogmatism, who have been formed by a dogmatic skepticism concerning final solutions. Ours, according to the Straussian view, is a time when it's even appropriate to say more openly than ever to men who want to hear it that they are distinguished, by their openness, from those who can't handle the truth that there's no other solution but the way of life of the philosopher. It's a time to display in neon letters the esoteric teaching of the philosophers, to turn esotericism into a kind of "ism." Esotericism becomes part of the exoteric teaching of Platonism. So Strauss says that the true philosopher is rare, and that any particular time and place is lucky to have even one. But he also makes the fact of and even some of the contents of the esoteric teaching meant for philosophers alone available for thousands and thousands in our time. The Straussian, apparently, is supposed to be somewhat confused about whether he himself is a philosopher, but he certainly takes pride in knowing much of what philosophers alone know.

Finding out, for example, that the philosophers have always been atheists or at least disbelievers in the religion of their time is indispensable for making them credible again in an age when God is dead. And separating genuine atheism from the progressivist delusions associated with historicism and connecting it again with the need for exotericism or the need-from which the few are liberatedto believe in personal significance and so moral purpose and divine providence can be the source of a kind of Platonist or Straussian responsible statesmanship. The future of esotericism - or the shared way of life of the philosophers - depends on the restoration of a credible exotericism freed up as much as possible by the unnecessarily and dangerously excessive personal delusions of both History and Christianity. Exotericism, of ourse, is directed by the esoteric insight that it's necessary but not really true; the error of both Christianity and History is the thought that human beings could truthfully depend on the Creator or creativity.

One place this exoteric esoteric Platonism originates, of course, is in the Republic, where we find the exaggeration of the completely liberated philosopher-king with the corresponding exaggeration of cave-dwelling citizens completely in the thrall of the manipulations of the city's poets. Total intellectual freedom is contrasted with total intellectual slavery, and so the philosopher-king finds no pleasurable fulfillment in merely ruling; controlling slaves is less wonderful, surely, than enjoying one's own selfsufficient liberation. But controlling slaves is, nonetheless, a necessary diversion from the philosopher's true calling. Those exaggerations, of course, are presented for the benefit of a group of young and idealistic men, who want what they do and think to be pure and have eternal significance. The city or ordinary human life is protected from their deep idealism by being emptied of all real significance, as are the particular lives of everyone but the philosopher. The philosopher-king, to be sure, is for all practical purposes a tyrant, but he doesn't find erotic fulfillment or true happiness in the necessity of tyrannizing. And only he is truly happy, just as the tyrant-a category that seems to include anyone who really enjoys ruling - is perfectly miserable.

But, in addition to the philosopher-king constructed in speech, we also see the heroic character of Socratescalled by Heidegger the purest thinker of the Westabout whom we only have hearsay evidence. Even the character Socrates-who himself is meant to be an idealized version of the historical Socrates - locates himself in the cave or is always less than confident about the purity of his thought. Platonism begins with Socrates's unrealistic or sublime idealization of what philosophy is and who the philosopher is for Glaucon's benefit. The philosopher-king is not really a philosopher but a wise man; he has an adequate grasp of the idea of the Good or the whole or not only Being but what gives Being its Beingness. Socrates, meanwhile, is, as far as we can tell, stuck with the work of purifying images and so with the conclusion that, very strictly speaking, he knows nothing at all. In distinguishing the philosopher Socrates from the unrealistically idealized philosopher-king, Strauss, on the level of the truth about the philosopher and philosophizing, liberated the true Plato from the doctrine of Platonism.

\section{The Image of Philosopher's Perfection}

Still, Straussian Platonism preserves the somewhat unrealistic praise of the philosopher as an image of perfection that detaches the young men, in some measure, from merely human or moral and political concerns. He does not present some airtight case for any particular logos that incorporates human beings into an account of necessartarian nature that is eternity. As Strauss says, it's modern thought - and not classical, Platonic thought - that's tied to a particular cosmology, some account of mechanistic, 
impersonal nature that's readily transformable by free persons. And even the image of the philosopher-the character Socrates - doesn't correspond perfectly to the life of any particular human being, including the historical Socrates.

After saying, quite implausibly, that the philosopher as philosopher is so detached from other human beings that he doesn't even know whether his neighbor is a member of his species or not, Strauss ends up admitting that the philosopher is merely as self-sufficient as humanly possible or is just less moved than others by the social passions that we all share. The philosopher as philosopher, the Platonist, will lack political ambition, but that's not to say that any real human being is a philosopher all the time. The philosopher as philosopher doesn't describe completely even the historical Socrates or the historical Strauss. Certainly Strauss didn't intend for many of his best students to lack political ambition. Strauss manages to say that the philosopher as philosopher differs both in kind and in degree from his fellow human beings. And that contradiction is meant to moderate political ambition or not to accomplish the undesirable and impossible mission of freeing Straussians from any concern for the things of this world, from, for example, love of their families, friends, and fellow citizens.

But knowing about the philosopher and his concerns is still meant to be enough to show that neither the city nor History will ever be a genuine whole or perfected in a way worthy of our deepest longings. It's the real or natural inability of the city to be perfected - and the corresponding real inability of the philosophers' pursuit of wisdom to turn into wisdom itself - that's part of the best evidence for the goodness of nature. What's good about our livesincluding our openness to eternity - is dependent on our invincible natural limitations, on our awareness, for example, of the necessity of the death of each of us. It's part of the goodness of nature that we're much more aware of eternal or at least permanent human problems than we are of any definitive solutions. It's in that sense, at least, that Strauss can reasonably say that the realm of freedom is a province of necessity.

\section{Necessity and the Person}

Strauss is right, of course, that we can't think reasonably of ourselves as wholly free from nature, of what we didn't create and wasn't necessarily created. We're animated and ennobled - in different degrees - by our openness to that truth. We have to act responsibly in light of - or even take responsibility for-what we can't help but know about our natural directedness and limitations. We don't make ourselves out of nothing. What we're given isn't almost worthless or just about nothing. The Historical idea of autonomous self-creation is a monstrous, ghostly exaggeration of our freedom. But I would add that every part of our biological being in the broadest sense is infused with our freedom, with who each of us is. And every manifestation of our freedom depends on our biology, on what we've been given by nature to think and do.

I would also add that, following our philosopher-pope, Being is personal insofar as our openness is personal, and this openness is quite inadequately expressed by Heideggerian Historical authenticity or resoluteness. Our openness is both personal and natural, insofar as we are hardwired, so to speak, to be persons. Being can't dispense with persons, because, as far we know, logos is personal insofar as the order of Being manifests itself to us only through personsthrough beings with not only logos but eros and will or creativity. We are open to eternity, as far as we can tell, only in time. And so in some sense our personality or our freedom and love are hardwired, so to speak, into Being itself. We are necessarily somewhat homeless-but not all that homeless - in the cosmos.

So it's true, it seems, that we're capable of doing even better than we know. No impersonal logos can account for the irreducible fact of the greatness of human freedom. Heidegger's historicism-although on one level very personal - in the most important respect abstracts from or just has contempt for personal moral responsibility. But moral responsibility, in truth, is ontologically grounded insofar as it's rooted in what we can't help but know and the experiences beings with logos, eros, and creativity can't help but have.

Still, it remains easy to see why Strauss would want to free logos from personal pretensions. Heidegger showed us that to be personal but amoral is to be an irresponsible monster who never has to say he's sorry. To be impersonal and amoral in the mode of Straussian Platonism detaches theory from both personality and morality. That means that those irreducible human phenomena can be what they are, even if they might be viewed as mere illusions from the perspective of the philosopher as philosopher. Strauss's polemic against History and for eternity is on behalf of history or just what people do over time and even on behalf of people and especially particular persons morally exaggerating the significance of what they do. From this view too, the extreme defense of the realm of necessity is also a defense of the realm of freedom. And extremism in defense of liberty, of course, is no vice.

\section{A Personal Conclusion}

I obviously dissent from the fundamental need for some complete return to Plato and Aristotle by agreeing with 
Christian and even modern thinkers that the person is the bottom line, that no human being is most fundamentally either a citizen or a philosopher. That doesn't mean I'm a "historicist" or convinced that our self-understanding develops or changes radically over time. Tocqueville was right when he claimed that Jesus Christ had to come down to earth to show human beings the ways in which they are all equally free persons; he showed them what has always distinguished members of our species. And seeing this truth about who we are doesn't depend on what the Christians believe about who Jesus is or about the Trinity. Tocqueville himself, of course, didn't share those beliefs. Nonetheless, he was able to show at least something close to the true or personal relationship between magnanimity and humility and greatness and justice in the service of elevating democracy.

I also disagree with many students of Strauss in not promoting a civil theology based on veneration of the greatness - both theoretical and practical — of our Founders. Our Founders, I've said, built better than they knew. Our grateful and loyal appreciation of their enduring practical accomplishments as statesmen engaged in prudent compromise does not mean they should be beyond criticism as political thinkers. We may have to think better than they did about the foundation of our creedal nation. Their deliberation should be a model for ours. Let me close with some provisional remarks that bring the thought of Straussperhaps the most impressive and among the most influential political philosophers in America's history-close to mine in other ways.

Natural right vs. History, or reason vs. revelation, or philosophy vs. law are surely rhetorically exaggerated as stark alternatives in Strauss's writing. America and Americans are impure - but strange and wonderfulmixtures of all those allegedly fundamental alternatives. Certainly our faith in the absolutism of the Declaration of Independence to which Strauss calls attention is partly grounded in a philosophical sense of self-evidence, partly in the revelation of a monotheistic personal God, and partly in grateful, traditional veneration for our law and our Founders. Our common faith, in fact, has its vitality in our refusal not to chose one form of extremism over another and in not regarding the truth we hold in common about who we are as some final solution.

Our Declaration's devotion to nature, Strauss (in Natural Right and History) agrees with John Courtney Murray, is compromised by Locke's proto-historicism (nature gives us self-creating beings nothing of value). Its devotion to reason, Strauss would say, is somewhat diluted by the legislative compromise that transformed the Nature's God of the philosophic Jefferson's first draft of the Declaration into also a providential and judgmental God. Strauss adds, however, that all universal moral law depends on mono- theistic revelation - on an omniscient and omnipotent God who's willful (or creative) and loving (or, as Chesterton says, a center of significance that gives us all significance). The God of any law - even of what we call natural lawcan't be a purely necessitarian "Nature's God."

So Strauss suggests in his criticism of John Dewey that he approved of the statesmanlike compromise in Congress between the Calvinists and the Lockean Deists that produced something better than the extremism of either of the parties to the compromise. It would be dangerous, Strauss even says, if our absolutism were simply philosophical absolutism. That sort of absolutism is the foundation of unscrupulous and extreme modern experimentalism encouraged by the philosophers driven by History. Our Founders did sometimes think of our Constitution as an unprecedented modern experiment, but they didn't think they were some modern equivalent of philosopher-kings.

Strauss, I think, would not have regarded the defense by some misguided Straussians of the "Nature's God" of the Declaration as liberated from personal, creationist premises as a promising way of fending off either the progressivist or relativist versions of historicism. The standard Lockean version of what that philosophic deity gives us, for one thing, is finally only negative. That God is indifferent to the personal being of each of us, and we are free-as historical or self-creating beings - to transform what he gave us with our personal significance in mind. The nominalism - the idea that words are tools for individual liberation and nothing more - characteristic of modern thought is already present in our Founders' Locke. Nor does it make much sense to justify our founding, as some Straussians do, as embodying some classical idea of natural right; no law, Strauss makes clear, can do that.

For Strauss, natural law is an oxymoron, and the Enlightenment effort to derive an effective morality merely from rational reflection on the interests we share in common is naive. Both Thomas Jefferson's confidence that our country could be graced by the effectual selection of natural aristocrats of wisdom and virtue to rule and The Federalist's Machiavellian controlled experiment of employing enduring institutions with teeth to solve the problem of the unreliability of character Strauss gently criticizes (as well as appreciates). Strauss's own view seems to be that public opinion informed by the moral absolutism of the Declaration of Independence, assisted by those strong institutions, might serve to contain the experimentalism of unscrupulous men, who, when safely checked, are often capable of producing good political results.

Many Straussians - to defend that civic morality - think they're stuck with the absolute defense of the American compromise as more than a compromise. Natural rights have to be exoterically defended in the esoteric light of 
natural right or what's best for philosophy as a way of life. But even the absolute defense of natural rights as universal moral law can't liberate "Nature's God," as the philosopher does esoterically, from the "exoteric" or civil theological creative and providential God. So Straussians are compelled not to write as atheists, too often they come off as seeming to believe more than is reasonable in America, with an incredible faith in our Founders as the wisest of men. They aren't so good in limiting government from the perspective of the person who is more than a citizen, whose political home is not his truest home. But the progress of our welfare state has showed us pretty clearly the unreliability of individual self-interest, by itself, as a brake on big government.

Those, such as the American Catholic Thomist John Courtney Murray, who defend the American compromise as the product of men building better than they knew, from Strauss's view, unreasonably believe that the Thomistic synthesis of Nature's God and the personal, creative God is actually reasonable. But we Thomists remember that Strauss also thought that impersonal Platonism and creative History are philosophic extremes, and that we can't know for certain that Being is anonymous or impersonal. We also remember with, I think, Lincoln (not to mention Chesterton-a huge admirer of Lincoln) that our belief in equal rights depends on a deeper belief in the equal significance of every human person.

It's far from clear, as I've explained, that personal-but not Historical-logos is an oxymoron. The rediscovery of the personal logos would be, for us, postmodern. It would combine the realism (as opposed modern nominalism or constructivism) of classical political philosophy with we can call Christian and modern personalism. The person, in fact, is not a Historical creation, and that's why, as a rational and erotic being open to the truth, he's stuck with virtue no matter how people transform their world. If we are persons by nature - as the beings hardwired, so to speak, for language or speech - then the good news is that the philosophers of History (including the Nietzscheans [including, at times, Strauss] who obsess about the possible coming of a Brave New World and its "last man") are wrong that we are given the freedom to make ourselves more or less than human - or more or less than persons. The bad news, in a way, is that we'll never be totally at home in the natural world, the political world, or some designed techno-world we create for ourselves.
Strauss was surely right that a somewhat vague idea of nature or natural right functioned well as a weapon against History, and Platonic philosophers, Lockean technoindividualists, and Biblical believers readily allied to defend natural human liberty against tyrannical efforts by the Communists at its Historical abolition. Personal destiny and responsibility, in fact, defeated the effort to reduce personsincluding even philosophers - to History fodder. Neither natural right nor History can explain the personal, courageous responsibility dissidents such as Solzhenitsyn took for defeating the impersonal lie that was Historical ideology. The disappearance of History with a capital " $H$ " was not the end of the free and responsible person. And it certainly was a defeat of the promise of modern atheism that we can create for ourselves a world so fulfilling or unalienated that God and religious longing would just wither away.

The defense of the goodness of nature, of course, becomes more urgent as the quackery of History is displaced by genuinely promising biotechnological efforts to alter our natures. And that defense can't be based, even esoterically, primarily on what's best for philosophers. In Huxley's Brave New World, for example, the alienated philosophers-"anybody who's anybody"-continue to dwell on the isles of the blessed (such as the Falklands and Iceland), while the great mass of people are reduced to subhumanity through the right mixture of mood altering chemicals and intrusive socialization in the name of happiness, as opposed to the alienated Lockean's joyless quest for joy.

The Brave New World, the book suggests, might not be so bad for philosophers, who won't be compelled but might be able to rule. Rights - including, for example, our right to our natural moods-make no sense unless it's really possible for ordinary persons to be both free and happy while assuming the responsibilities we all share. And so it seems more true than ever that neither "natural right" nor "History" is the solution, because neither captures adequately who we are.

Peter Augustine Lawler is Dana Professor of Government at Berry College and executive editor of the scholarly quarterly Perspectives on Political Science. He served on President Bush's Council on Bioethics. His latest book is Modern and American Dignity (ISI Books). 